\title{
Consumer Attitudes toward Mobile Advertising: An Empirical Investigation among China Users
}

\author{
Xiao Shuang \\ School of business, jianghan University, Wuhan, P.R. China, 430056
}

\begin{abstract}
Mobile advertising represents a significant development in advertising. Despite the potential of mobile advertising, consumer attitude towards mobile advertising is a major obstacle in its adoption and development. The focus of this research is to develop a framework to identify the factors influencing consumer attitude toward mobile advertising. We test the model through an empirical investigation using structural equation modeling techniques. User data collected from the survey are used to set the prior hypothesis. Firstly the results suggest that the entertainment, information and personalization have a significant positive influence on the attitudes toward mobile advertising. secondly there is also a positive and direct influence of interactivity on customer attitude.
\end{abstract}

KEYWORD: Mobile advertising; Attitude toward the mobile advertising; interactivity

\section{INTRODUCTION}

Consumers' attitude toward advertising has been found to influence advertising effectiveness[1]. Mehta found that those who have more positive attitude toward advertising are more likely to be persuaded by advertising. So, consumers' positive attitude toward mobile advertising is likely to influence the adoption of mobile advertising. As of June 2014, the scale of China's mobile phone users reached 527 million, representing an increase of 2,699 people by the end of 2013, the first time beyond the scale of mobile phone users traditional PC netizens[2]. Therefore, advertisers increasingly dependent on modern mobile devices such as mobile phones to promote products and services. Tsang stated that entertainment was found to be the most important factor contributing to positive attitudes toward mobile advertising ${ }^{[3]}$. Mobile advertising is creating a new marketing and advertising channel and has the potential to reach millions of wireless devices at the right time, the right place and the right consumer. Moblie advertising is a real opptunity for enterprises to get new marketing and consumers. Firstly, develop a framework to identify the factors influencing consumer attitude toward mobile advertising, and then We test the model through an empirical investigation using structural equation modeling techniques. We sent out 350 questionnaires and received 321returned ones. The invalid and incomplete questionnaires were eliminated, at the end, we obtained 298 valid responses for our research. User data collected from the survey are used to set the prior hypothesis. Results showed that perceived entertainment, information and perceived interactivity have significant influence on consumers' mobile advertising attitude, perceived interactivity is the most important factor and Personalized have a positive impact on the consumer attitude toward mobile advertising.

\section{RESEARCH MODEL AND HYPOTHESES}

\subsection{Entertainment}

Tsang found entertainment to be the significant factors affecting repondents' attitudes toward mobile advertising[3]. Entertaining advertising content and value of traditional advertising has a significant relationship. Highly entertaining for the user's mood and have a positive impact on the subjective perception [4]. Entertainment is an important factor of mobile marketing, the information should be concise Interestingly this is the basic requirements of mobile advertising, so as to capture the immediate attention of consumers, entertainment performance increase customer loyalty, providing games and prizes to the user's mobile phone is a effective way to attract and maintain customers. Therefore, based on previous research, we have: 
H1: mobile advertising entertainment content have a significant positive influence on the attitudes toward mobile advertising.

\subsection{Informational}

Information refers to the ability to effectively provide relevant information [5]. the transmission of information via mobile devices also need to have accuracy, timeliness and usefulness of features ${ }^{[6]}$. Tsang found informativeness to be the significant factors affecting respondents" attitudes toward mobile advertising[3]. In addition, users need to quickly get the information they need, consumers can get personalized information in accordance with their interests [7]. Thus, based on the above analysis, we hypothesize:

$\mathrm{H} 2$ : mobile advertising informational have a significant positive influence on the attitudes toward mobile advertising.

\subsection{Interference}

If people feel mobile advertising has hurt their dignity, the attitude of the user mobile advertising have a significant negative impact. If the mobile advertising becomes annoying, unpleasant, excessive manipulation of consumers, consumers do not want to receive advertising[8]. Mobile advertising provides a lot of information, so that adopters feel very confused, this will have a negative impact. In addition, some consumers do not want to see spam messages, thus, we believe that interference has a negative impact on the user's mobile advertising attitude.

H3: interference of mobile advertising has a significant negative influence on the attitudes toward mobile advertising.

\subsection{Credibility}

Advertising credibility consumers generally perceive advertising is real and credible [9]. Brackett and Carr believes the credibility of online advertising has a significant relationship with the customers' attitudes online advertising [10]. Tsang found creditability to be the significant factors affecting repondents' attitudes toward mobile advertising[3].based on this, we propose the following hypothesis:

H4: Credibility has a significant positive influence on the attitudes toward mobile advertising.

\subsection{Personalization}

Turban et al. modified this model for the ecommerce environment, stating that the buyer's individual characteristics, the environment, and the merchant' smarketing strategy [11]. customer personalization features including customer names, background information, customer interests and hobbies as well as terminal device information. Mobile operators can be found in the demographic, geographic information, the customer 's hobbies and interests, sales and price situation, the mobile advertising can accurately find the target customers. Rao and Minakakis discussed the need for marketing based on customer knowledge [12], based on customer feedback, ads can consider the location, time and other factors. Customers' personal characteristics variables such as gender, age and income and education levels of their advertising attitude is also influential in mobile commerce. Hence, we have:

H5: personalized mobile advertising has a significant positive influence on the attitudes toward mobile advertising.

\subsection{Perceived Interactivity}

The importance of interactivity will increase in mobile advertising since it is one of the most characteristics of mobile communications. Interactivity means continuous exchange of views, marketers and consumers can interact with mobile devices. Interactive advertising is more than one way of advertising to attract the user's attention [13]. Cho, CH and Leckenby, JD (1999) study shows that interactivity have a positive influence on the attitudes toward mobile advertising [14]. Based on previous research, we have:

H6: Perceived interactivity has a significant positive influence on the attitudes toward mobile advertising

We summarize our research model and hypothesis in figure1:

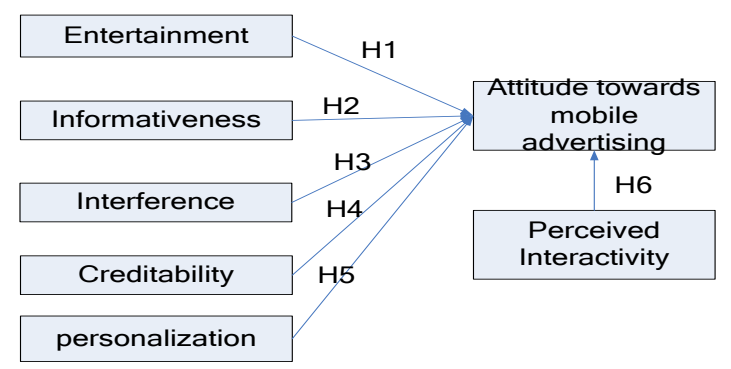

Figure1. Proposed model of Consumer attitudes toward mobile advertising

\section{EMPIRICAL INVESTIGATION}

\subsection{Data Collection and Data Analysis using PLS software}

We conducted a field survey consisting of a questionnaire designed to collect data regarding the effect of attitude towards advertising. Data from the study questionnaire items measure all variables are 
from the existing literature, the definition of variables,

We used SPSS13.0 to test the reliability and validity of the model and used Partial Least Squares (PLS) to analyze the data.

\subsection{Hypothesis testing}

We used PLS-Graph3.0 to analysis our collected data. The path coefficient were showed in Figure 2.T-statistics confirmed that all hypothesized paths except four were significant. mobile advertising entertainment, informativeness and personalization content have a significant positive influence on the attitudes toward mobile advertising, Perceived interactivity has the most significant influence on the attitudes toward mobile advertising, whereas interference and credibility were not significant influence on the attitudes toward mobile advertising. Test results are shown in Figure 2:

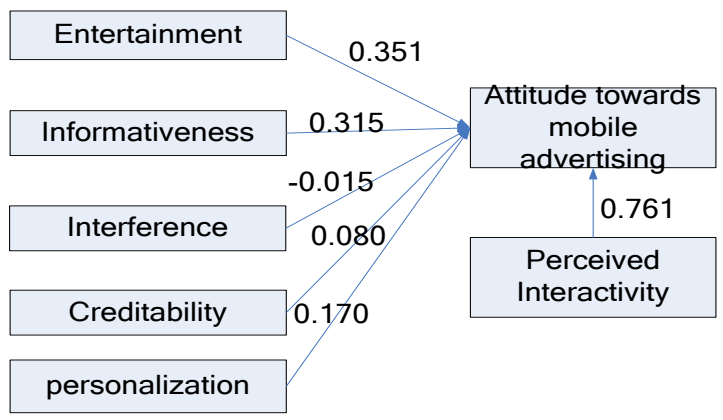

Figure 2.Hypothesis testing results $(\mathrm{p}<0.05)$

\section{CONCLUSIONS}

This paper has proposed a theoretical model to explain and pedict consumer attitude toward mobile advertising by using the constructs of identify the factors influencusing consumer attitude toward mobile advertising. Our results confirm that: the entertainment, informational and personalization aspects perceived by consumers in mobile advertising a significant positive influence on the attitudes. there is also a positive and direct influence of interactivity on customer attitude. Mobile campaigns are focused mainly on mobile advertising interactivity. In fact, interactivity is the most important factor influence on attitude in this reseach.
This suggests that companies should strengthen mobile advertising' interactivity with customer in order to improve consumers' attitude toward mobile advertising and its effectiveness. Our model has good explanatory power in predicting consumer attitude toward mobile advertising.

\section{REFERENCES}

[1] Mehta, A., 2000, Advertising attitudes and advertising effectiveness. Journal of advertising reseach 40(3), 67-71.

[2] http://tech.163.com/14/0721/13/A1MARR19000915BF.ht ml(accessed 15 september 2014),2014

[3] Tsang,m.m., Ho,S., liang,T., 2004. Consumer attitudes towords mobile advertising: an empirical study. International Journal of Electronic Commerce8(3), 65-78.

[4] Hoffman, D. L. and T. Novak, P. Marketing in Hypermedia Computer-Mediated Environments: Conceptual Foundations. Journal of Marketing. 1996, 60(7):50 - 68

[5] Lih-Bin $\mathrm{Oh}$ and Heng $\mathrm{Xu}, \mathrm{H}$. 'Effects of multimedia on mobile consumer behavior: an empirical study of location aware advertising. 2003 - Twenty-Fourth International Conference on Information Systems2003:679-691.

[6] Siau, K. and Z. Shen. Building Customer Trust in Mobile Commerce. Communications of the ACM, 2003. 46(4), 91 $-94$.

[7] Robins, F. The Marketing of 3G. Marketing Intelligence \& Planning, 2003, 21(6): 370 - 378.

[8] Ducoffe, R. H. Advertising Value and Advertising on the Web. Journal of Advertising Research.1996, 36:21 - 36.

[9] MacKenzie, S. B. and R. L. Lutz. An Empirical Examination of the Structural Antecedents of Attitude Tow- ard the Ad in an Advertising Pretesting Context. Journal of Marketing.1989, 53(3):48 - 65.

[10] Brackett, L. K. and B. Carr, N. Cyberspace Advertising vs. Other Media: Consumer vs. Mature Student Attitudes. Journal of Advertising Research, 2001, 41(5): 23 - 32.

[11] E.Turban, N.Lee, D.King, H.M.Chung, Electronic Commerce-A Managerial Perspective. Prentice Hall, 2000.

[12] B. Rao, L. Minakakis. Evolution of mobile location-based services. Communications of the ACM. 2003, 46 (12).

[13] Lohtia, R., Donthu, N., \& Hershberger, E. K. The Impact of Content and Design Elements on Banner Advertising Click-through Rates. Journal of Advertising Research, 2004. 43(4):410-418.

[14] Cho, C. H., \& Leckenby, J. D. Interactivity as a measure of advertising effectiveness: antecedents and consequences of interactivity in web advertising. In M. S. Roberts, 1999 Conference of the American Academy of Advertising.1999:162-179. 